\title{
Insulin-like growth factor-1 gene expression in the endometrium of repeat breeder cows after the administration of presynch-10 and ovsynch protocol
}

\author{
Ali Reha AĞAOĞLU ${ }^{1, a, \varpi}$, Özgecan KORKMAZ AĞAOĞLU ${ }^{2, b}$, Özge SIDEKL $\dot{I}^{2, c}$, \\ Mesih KOCAMÜFTÜOĞLU ${ }^{1, d}$ \\ ${ }^{1}$ Burdur Mehmet Akif Ersoy University, Faculty of Veterinary Medicine, Department of Obstetrics and Gynecology, Burdur; ${ }^{2}$ Burdur \\ Mehmet Akif Ersoy University, Faculty of Veterinary Medicine, Department of Animal Science, Burdur, Turkey. \\ ${ }^{\mathrm{a} O R C I D: 0000-0002-6545-8800}$; ' ORCID: 0000-0002-7414-1725; ' $\mathrm{CRCID}$ : 0000-0002-4891-1968; \\ dORCID: 0000-0003-3228-6835 \\ ${ }^{\triangle}$ Corresponding author: rehaagaoglu@mehmetakif.edu.tr \\ Received date: 30.10.2019- Accepted date: 30.12.2019
}

\begin{abstract}
The aim of this study was to investigate the effects of using presynch-10 and ovsynch synchronization protocols on endometrial expression and serum levels of insulin-like growth factor-1 (IGF-1) that thought to play roles during endometrial healing process in cows diagnosed with repeat breeder syndrome (RBS) and subclinical endometritis (SE). A total of 40 Holstein-Friesian cows identified as having RBS and SE were used. The animals in Group $1(\mathrm{G} 1, \mathrm{n}=20)$ were applied presynch-10 and ovsynch furthermore, biopsy and blood samples were collected both before and after administration. Biopsy and blood samples were taken from the animals in Group $2(\mathrm{G} 2, \mathrm{n}=20)$ without performing any synchronization. The $I G F-1$ gene expression profiles were determined in all samples using RT-qPCR. Even though the level of IGF-1 expression increased in samples taken after synchronization in G1, it was not statistically significant $(\mathrm{P}>0.05)$. There was no statistical difference in serum IGF-1 levels between $\mathrm{G} 1$ and $\mathrm{G} 2(\mathrm{P}>0.05)$. In conclusion, the expression of the IGF-1 gene in the endometrial tissue of RBS cows with SE was identified, but the evidence suggests that the synchronization protocols in question had no significant effect on the gene expression profile being investigated.
\end{abstract}

Keywords: Gene expression, $I G F-1$, ovsynch, presynch-10, repeat breeder

\section{Presynch-10 ve ovsynch protokolleri uygulamasından sonra repeat breeder ineklerde endometriyal insülin benzeri büyüme faktörü-1 gen ekspresyonu}

Özet: Bu çalışmada; repeat breeder sendromu (RBS) olan ve subklinik endometritis (SE) olduğu belirlenen ineklerde uygulanan presynch-10 ve ovsynch senkronizasyon protokollerinin, endometriyal iyileşme sürecinde rol oynadığı düşünülen insülin benzeri büyüme faktörü-1'in (IGF-1) endometriyal ekspresyonu ve serum düzeyleri üzerine etkilerinin araştırılması amaçlanmıştır. Çalışmada RBS olan ve SE tespit edilmiş toplam 40 baş Holstein-Friesian inek kullanılmıştır. Grup 1'de bulunan hayvanlara (G1, n=20), presynch10 ve ovsynch uygulanmış, ayrıca uygulama öncesi ve sonrasında biyopsi ve kan örnekleri alınmıştır. Grup 2'de bulunan hayvanlara $(\mathrm{G} 2, \mathrm{n}=20)$ herhangi bir senkronizasyon uygulaması yapılmadan sadece biyopsi ve kan örnekleri alınmıştır. Tüm örneklerde RT-qPCR ile $I G F-1$ geninin ekspresyon profilleri belirlenmiştir. G1'de senkronizasyon sonrası alınan örneklerde $I G F-1$ ekspresyon düzeyinde bir yükselme şekillenmiş olsa da istatistiksel olarak bir önem bulunamamıştır ( $\mathrm{P}>0,05)$. G1 ve G2 arasında serum IGF-1 seviyesi açısından da istatistiksel bir fark oluşmamıştır ( $\mathrm{P}>0,05)$. Sonuç olarak; SE tespit edilen RBS'li ineklerin endometriyal dokularında $I G F-1$ geninin eksprese olduğu belirlenmiş ancak kullanılan senkronizasyon protokollerinin, incelenen genin ekspresyon profili üzerine anlamlı bir etkisinin olmadı̆̆ı sonucuna varılmıştır.

Anahtar sözcükler: Gen ekspresyonu, $I G F-1$, ovsynch, presynch-10, repeat breeder.

\section{Introduction}

Repeat breeder syndrome (RBS) is a substantial problem that causes infertility in the dairy herds (36) and occurs at the frequency of $7-36 \%(19,38,39)$. RBS causes significant economic losses since especially it prolongs calving-conception interval and increases the culling rates of cows in herds $(14,34)$. Even though there are a number of factors that play a role in the etiology of RBS, the major causes can be listed as subclinical endometritis (SE), luteal deficiencies, delayed ovulation and malnutrition, which cause embryonic death or fertilization errors $(1,19,23$, 38). One of these problems is luteal insufficiency that 
leads to low serum progesterone levels and embryonic deaths (20). Low progesterone levels may lead to lower interferon-tau secretion of the embryo, which causes early lysis of the corpus luteum (21). Similarly, endocrine asynchronization, which means that hormones are not released when they should be, causes delayed or absence preovulatory luteinizing hormone (LH) surge. Depending on this situation; progesterone level remains low and, embryonic deaths and RBS may occur $(3,4,11)$. Another condition that causes RBS is SE. It is a superficial inflammation characterized by degradation and congestion in the epithelial cells of the cows' endometrium and infiltration of inflammatory cells without any purulent discharge and uninterrupted continuation of the sexual cycle (15). Cows with SE do not show any clinical signs of endometritis and they have very low chances to become pregnant after artificial insemination (AI). Studies have shown that the prevalence of SE in cows with RBS varies between $15 \%$ and $50 \%(12,24,28)$. A number of factors play a role in the development of these disorders that cause RBS. In this context, reproductive activities in cows, as in all other mammals, are regulated by the harmonious interaction of the hypothalamic-hypophyseal-ovarian axis. It has been revealed that during this interaction, growth hormone and insulin-like growth factor play crucial roles, like as hypothalamic-hypophyseal-ovarian axis derived hormones $(18,31) . I G F-1$ is synthesized and secreted in the liver due to the effect of growth hormone (26). IGF-1 does not only affects ovarian functions, oocyte quality and viability of the embryo, but also the endometrium (33). For instance; it was determined the members of the $I G F$ system that have a stimulating effect on the regeneration of damaged epithelial cells in the process of tissue repair and in the production of new cells (5). Endometrial cells are also specific epithelial cells of the uterus and, IGFs are expressed in varying amounts in endometrium in various species such as rodents (8), pigs (29), cattle (7) and, sheep (32). Moreover, it has been demonstrated that IGFs have both progressive or regressive effects on uterine tissue depending on the stage of the sexual cycle. In this context, it was determined that post-partum cows with low IGF-1 concentrations are more sensitivity to endometritis (35). There are many causative factors in the etiology of bovine RBS, therefore, treatment methods are also preferred according to the etiology. In the treatment for RBS that develops due to hormonal dysfunction or SE, it should be focused on the treatment of endometritis or regulation of ovarian function. From this perspective, one of the preferred treatments of RBS with endometritis is the application of the "ovsynch" protocol which controls ovarian functions (25). The ovsynch method is preferred the treatment of RBS with SE because it ensures regular follicular development and ovulation, stimulates the regeneration of endometrial epithelium. Furthermore, it stimulates the immune system due to the resulting estrus and, the prostaglandins used in this method are thought to stimulate the local immune response of the uterus. The aim of this study was to determine how endometrial $I G F-1$ gene expression levels and serum IGF-1 levels in RBS cows cytologically diagnosed with SE, are affected by presynch-10 + ovsynch applications.

\section{Material and Methods}

Animals: The animal material for the study has consisted of 40 Holstein-Friesian cows bred on dairy farms and identified as having RBS. All of the procedures conducted on the cows were approved by the Local Ethics Committee on Animal Experiments (Approval no: 2019519). Repeat breeder cows were identified by examining farm records and conducting gynecological examinations. Cows that had given birth at least once and were inseminated in three consecutive estrus cycles yet failed to get pregnant were identified based on farm records. Rectal palpations and USG examinations were conducted on these cows to determine whether there were any pathological issues in the uterus or ovaries. Clinical pathological conditions were excluded from the study. The cows included in the study had corpus luteum on the ovaries and body condition scores between 3.0-3.5 under the scoring system with 1 to 5 scales. An endometrial cytology sample was taken from all of the cows included in the study to determine the endometrial polymorphnuclear lymphocyte (PMNL) ratio, an endometrial biopsy to determine gene expressions, and a blood sample from the tail vein to measure serum $I G F-1$ levels. The days in milk (DIM) information and the calving-first service interval of cows were determined based on farm records. In the cytological evaluation, cows with PMNL ratios $\geq$ $3 \%$ were considered to be SE (28) and included in the study. The cows were randomly divided into two groups (G1 and G2).

Experiment 1: The presynch-10 + ovsynch protocol was administered to the cows in Group $1(\mathrm{G} 1, \mathrm{n}=20)$ and the same samples were repeated 10 days after the last injection (Figure 1).

Experiment 2: No synchronization protocol was administered to the cows in Group $2(\mathrm{G} 2, \mathrm{n}=20)$. After waited for the length of time required by the synchronization protocols administered to G1 (34 days), estruses were monitored. Ten days after estruses were determined, rectal examinations were performed and all samples were collected again from cows with corpus luteum (Figure 2).

Collection of endometrial cytology samples: A cytobrush (Cytobrush $^{\circledR}, \quad$ Ref.17214/2960, Minitube, Germany) was used to determine the neutrophil concentration. In order to prevent the cytobrush from being contaminated during this procedure, it was inserted 


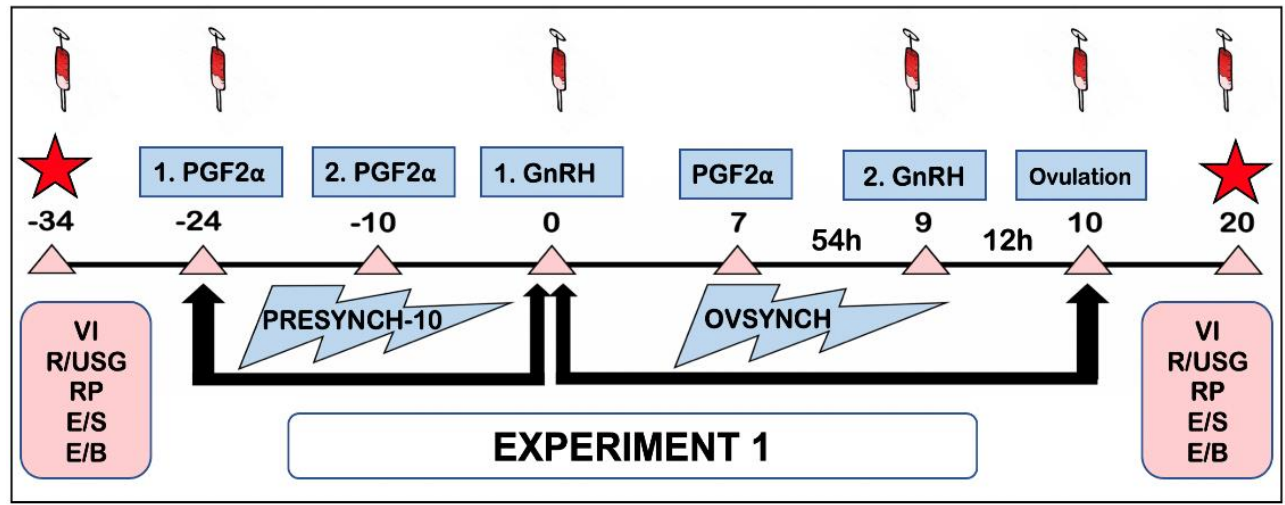

Figure 1. Presynch-10 + ovsynch protocol

PGF2 $\alpha$ : Cloprostenol, $500 \mu \mathrm{g}$, im, Estrumate ${ }^{\circledR}$, Intervet; GnRH: Buserelin acetate, $10 \mu \mathrm{g}$, im, Receptal ${ }^{\circledR}$, Intervet; VI: Vaginal Inspection; R/USG: Rectal ultrasonography; RP: Rectal palpation; E/S: Endometrial swab; E/B: Endometrial Biopsy; Syringes: collecting blood samples; Stars: collection tissue samples.

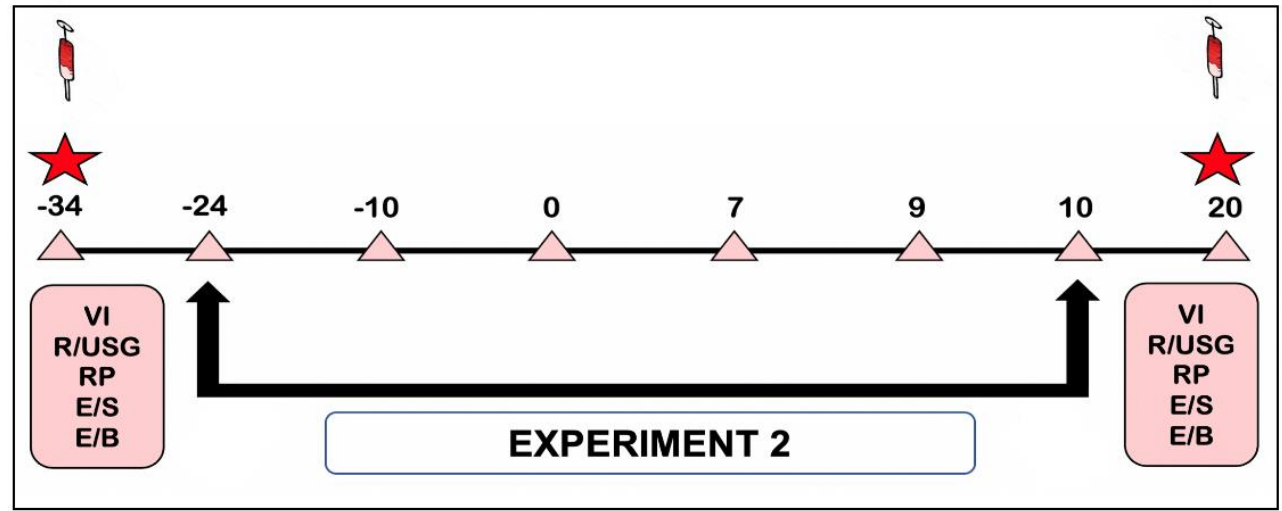

Figure 2. Control group

VI: Vaginal Inspection; R/USG: Rectal ultrasonograpy; RP: Rectal palpation; E/S: Endometrial swab; E/B: Endometrial Biopsy; Syringes: collecting blood samples; Stars: collection tissue samples.

into the uterus lumen inside a stainless-steel metal catheter approximately $50 \mathrm{~cm}$ long. After the sample was taken, it was smeared on a slide with the brush. The collected samples were stained using the May Grunwald Giemsa staining method and 200 cells were counted in each preparation microscopically.

RNA isolation and cDNA synthesis: The endometrial biopsy samples were collected from the dorsal wall and intercaruncular site of the uterus with biopsy forceps (Kruuse Biopsy instrument, Denmark). The collected tissues were placed in $1.5 \mathrm{ml}$ microcentrifuge tubes and frozen in liquid nitrogen. The samples were taken to the laboratory in a nitrogen tank and stored in a deep freeze at $-86^{\circ} \mathrm{C}$ until the analyses were performed. Homogenization of frozen endometrial tissue samples was performed using the TRIzol $^{\circledR}$ (Invitrogen, USA) method. DNA digested with DNase-I (Fermentas). And, the commercial kit (Thermo Scientific RevertAid ${ }^{\mathrm{TM}}$ First Strand cDNA Synthesis Kit) was used to cDNA synthesis.

$\boldsymbol{R T}-\boldsymbol{q P C R}$ : YHWAZ was used as the reference gene as it is most stable and suitable for the study (2). And, a pair of specific primers [Forward: 5'-
CTGAGCAAGGAGCTGAATTATC-3' and Reverse: 5'CTCTGTATTCTCGAGCCATCT-3 for YHWAZ (NM_174814.2)] was designed using the idt/PrimerQuest and ncbi/tools/primer-blast software to amplify fragment of the YHWAZ gene consisting of $162 \mathrm{bp}$. (2). For the IGF-1 gene, the primers designed by Yoshida et al. (37) [Forward: 5'-TCAGTTCGTGTGCGGAGACA-3' and Reverse: 5'-ACTTCCTTCTGAGCCTTGGG-3' for IGF1(NM001077828)] were used to amplify a region consisting of $222 \mathrm{bp}$. Primer efficiencies were determined using two-fold serial dilutions of cDNA. The expression profiles for YHWAZ and $I G F-1$ genes were identified with RT-qPCR, using a ROCHE Nano Lightcycler ${ }^{\circledR}$. The reaction was prepared using SYBR Green Master Mix (2X). This procedure was performed twice. Melting curve analyzes were performed.

Hormone measurements: Hormone analyses were performed in a private laboratory with international accreditation (TÜRKAK, TS EN ISO/IEC 17025:2005 Experimental Laboratory) using ECLIA $^{\circledR}$ (Electrochemiluminescence Immunoassay) for estradiol and progesterone, and $I G F-1$ specific ELISA kit (CusaBio ${ }^{\circledR}$, Bovine insulin-like growth factor 1, ELISA Kit). 
Statistical analysis: MINITAB $16.0^{\odot}$ was used for the statistical analysis of the data. It was later normalized with the data reference gene obtained from the qPCR analyses based on the delta delta $\mathrm{Ct}$ mathematical model reported by Livak and Schmittengen (16). The paired t test was used for data collected from the same group while the $\mathrm{T}$ test and One-way ANOVA were used to identify differences between the groups. Box plot and Interval Plot graphics were created for a visual representation of the data.

\section{Results}

The calving-first service interval and the DIM numbers were $85.95 \pm 19.79$ and $205.6 \pm 55.60$ for $\mathrm{G} 1$ and $90.05 \pm 21.77$ and $236.25 \pm 54.51$ for $\mathrm{G} 2$ respectively. The mean DIM numbers for the cows in G1 and G2 were 205.60 \pm 55.60 (min. 150, max. 349), so cows with PMNL
$>\% 3$ during the cytological evaluation were considered to have SE (31).

Expression of IGF1 gene: The IGF-1 gene was expressed in all samples. The resulting RT-qPCR products using YHWAZ as the reference gene and the $I G F-1$ gene in bovine endometrium were separated with electrophoresis on $2 \%$ agarose gel and stained with ethidium bromide (Figure 3 ).

When the $I G F-1$ expression profile was examined depending on days of applied synchronization protocols, there was more expression in the endometrial biopsy samples taken after synchronization. However, it was not statistically significant $(\mathrm{P}>0.05)$. Expression levels between the biopsy samples taken in $\mathrm{G} 2$ remained almost the same. The Box Plot graphics that compare the data obtained after normalization of the $I G F-1$ gene RT-qPCR results with each sampling group are provided in Figure 4.

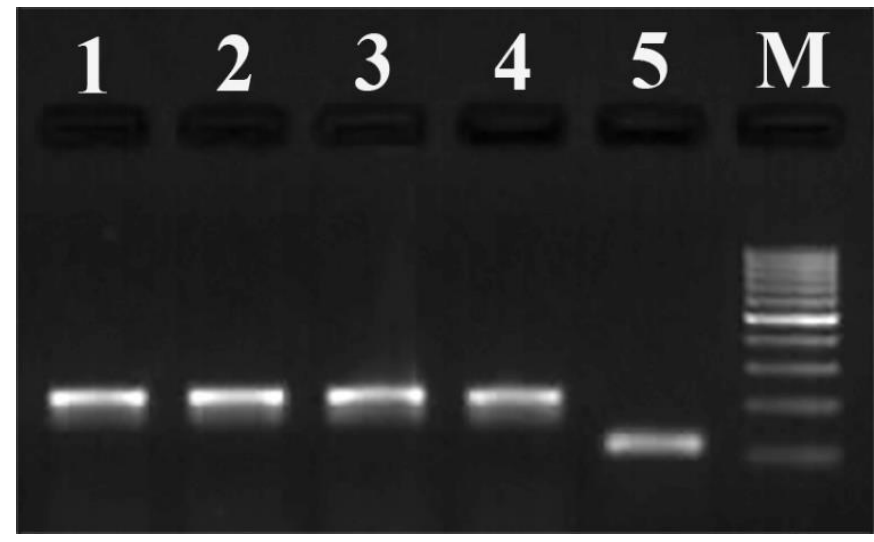

Figure 3. Expression of YHWAZ and IGF-1 genes at mRNA levels in bovine endometrium on $2 \%$ agarose gel.

Lanes 1-4: PCR products of IGF-1 (222 bp), lane 5: YHWAZ (162 bp), M: 100 bp DNA ladder

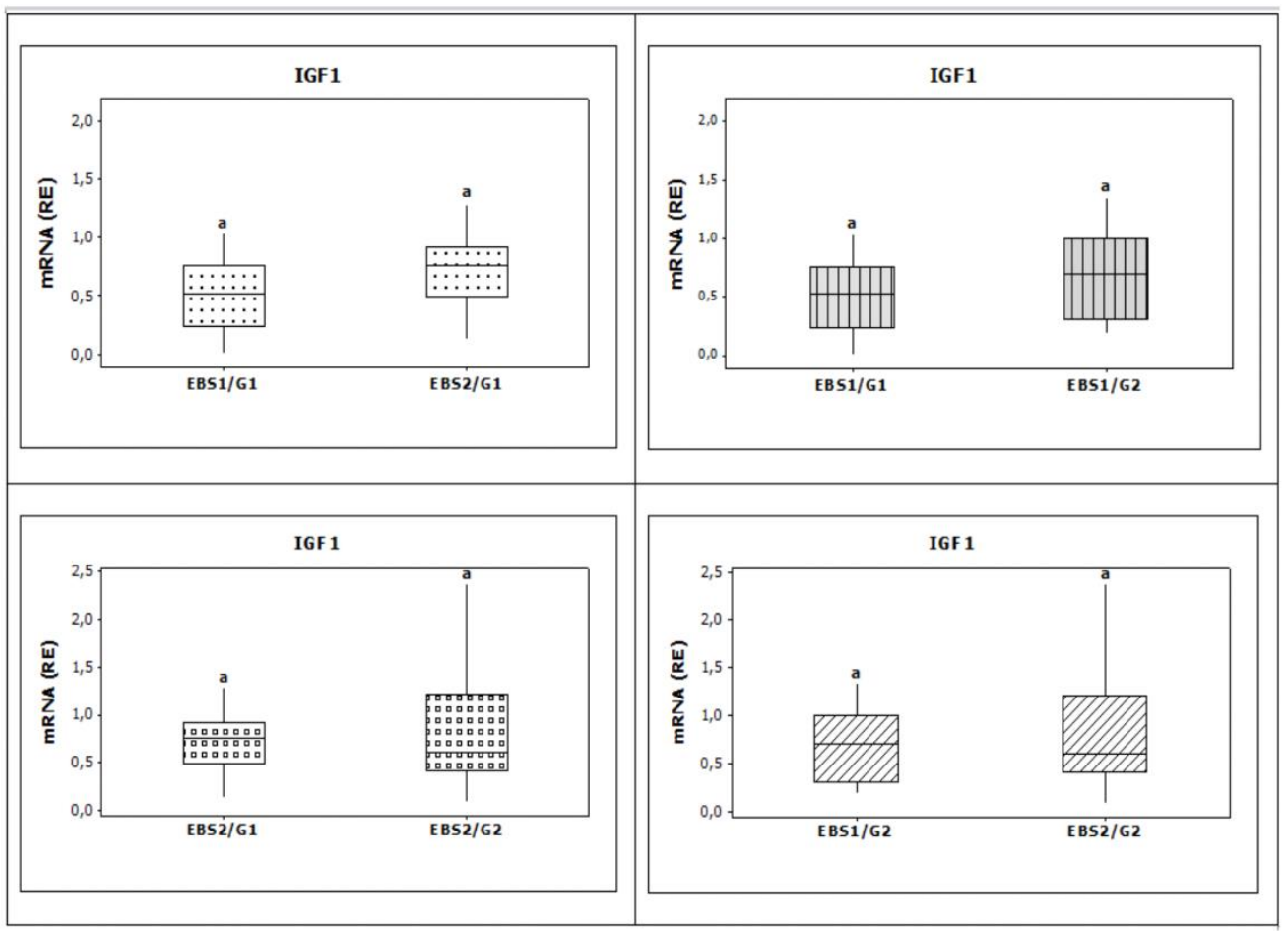

Figure 4. Box plot graphics showing the differences between sampling groups. EBS: endometrial biopsy sample. 
Interval Plot of IGF1 ng/ml

$95 \% \mathrm{CI}$ for the Mean

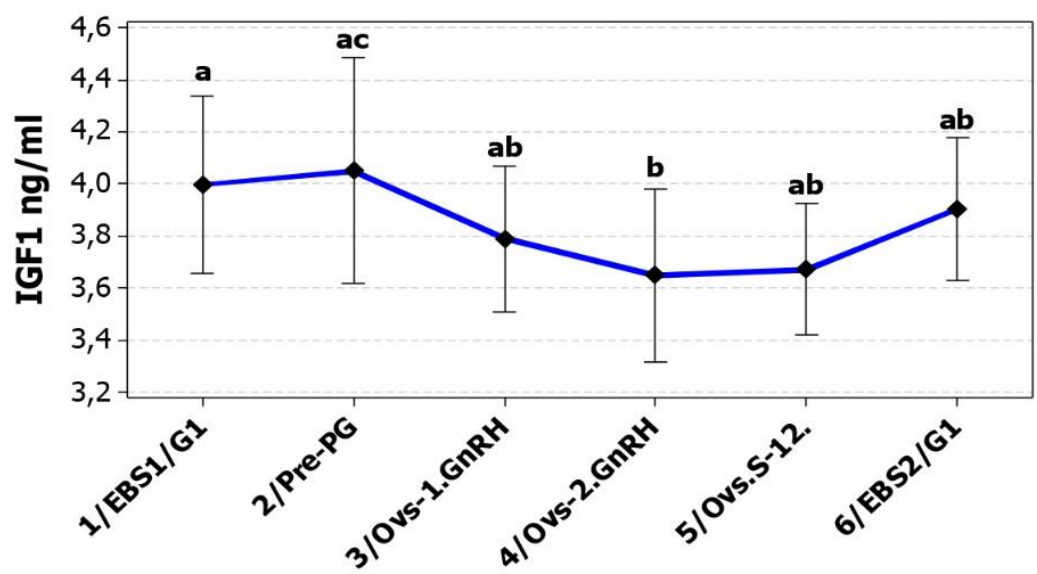

Figure 5. Serum IGF-1 levels according to administration days in G1.

a:b, P<0.05; c:b, P<0.05, 1/EBS1/G1: Group 1 Endometrial biopsy sample 1; 2/Pre-PG: presynch-10 $1^{\text {st }}$ Prostaglandin injection; 3/Ovs$1^{\text {st }} \mathrm{GnRH}$ : ovsynch $1^{\text {st }} \mathrm{GnRH}$ injection; 4/Ovs-2 ${ }^{\text {nd }} \mathrm{GnRH}$ : ovsynch $2^{\text {nd }} \mathrm{GnRH}$ injection; 5/Ovs.S-12: After ovsynch 12 hours; 6/EBS2/G1: Group 1 Endometrial biopsy sample 2.

When serum IGF-1 levels were examined, it was showed that the $I G F-1$ level of $3.99 \mathrm{ng} / \mathrm{ml}$ on the day the first sample was taken in G1 fell to $3.64 \mathrm{ng} / \mathrm{ml}$ on the day that the second GnRH administration of ovsynch was performed and that this decline was statistically significant $(\mathrm{P}<0.05)$. No statistically significant difference was found between the $I G F-1$ levels $(4.04 \pm 0.92 \mathrm{pg} / \mathrm{ml})$ measured on the day when the $1^{\text {st }}$ PGF2 $\alpha$ injection of presynch-10 was performed and on the day when $2^{\text {nd }} \mathrm{GnRH}$ injection of ovsynch $(3.64 \pm 0.54 \mathrm{pg} / \mathrm{ml})(\mathrm{P}<0.05)$. There was also no statistically significant difference in terms of serum IGF1 levels between the day on which the first sample was taken and the days on which the second sample was taken ( $\mathrm{P}>0.05$ ) (Figure 5).

No statistically significant difference was found between $I G F-1$ levels in the blood samples collected on the days when the first and second samples were taken in G2 ( $1^{\text {st }} I G F-1$ value: $3.99 \pm 0.73,2^{\text {nd }} I G F-1$ value: $4.09 \pm 0.75)$.

\section{Discussion and Conclusion}

The healing of damaged epithelial tissue consists of proliferation and remodeling processes (10). IGF-1 is an important factor that functions in the tissue repair process by stimulating epithelization and regeneration (5). Physiological regeneration of endometrial tissue takes place during the post-partum period in cows. Increased endometrial IGF-1 gene expression has been determined during the post-partum period in cows, and it has been demonstrated that the IGF-1 may play an important role in the endometrial repair process (17). Because a certain amount of endometrial injury occurs in cases of bovine $\mathrm{SE}$, there might be a connection between IGF-I and the injury and subsequent healing that occurs. In a study of the issue, endometrial $I G F-1$ expression was reported to be higher in cows diagnosed with metritis or clinical endometritis than in healthy cows or cows with SE. The same study found that when RBS cows with SE were compared with cows that did not have SE, endometrial $I G F-1$ expression was higher in the cows with SE. It was concluded that both of these findings could be related to the tissue damage in the endometrium and the healing process (13). Ovarian steroids are reported to have an effect on endometrial $I G F-1$ expression. In cows, it has been shown that endometrial IGF-1 expression peaks during the estrus stage when the estradiol level is highest in the estrus cycle (27). In this study, presynch-10 and ovsynch administrations given for treatment purposes to RBS cows induced ovulation, meanwhile, increased serum estradiol levels due to the follicular development that occurs. When the $I G F-1$ expression profile based on days of administration examined that showed an increasing in IGF-1 expression but the difference between the biopsy samples taken before and after synchronization in G1 was not statistically significant. It is thought that the increase in the expression of $I G F-1$ may be associated with the fact that the endometrium is exposed to estradiol as a result of the synchronization protocols applied.

In a study that examined bovine serum IGF-l levels during ovsynch administration that the serum $I G F-l$ levels decrease after the 1st GnRH injection of ovsynch but later increase until day 9 after the PGF2 $\alpha$ in cows and this occurred due to follicular development (6). It has also been demonstrated that $I G F-1$ is synthesized not only in the follicles of in bovine ovaries but in luteal tissue as well. However, after lysis of the luteal structure due to PGF2 $\alpha$ 
stimulation, there is no significant decrease in $I G F-1$ expression has been demonstrated (22). Moreover, it has been shown that ovulation occurred before the peak of plasma estradiol level at the time of second GnRH injection during ovsynch administration in cows (30). This finding indicates that the $I G F-1$ concentration in circulation is controlled by several different mechanisms.

It is thought that the reason why there is no difference in serum IGF-1 levels between on the day of the first PGF $2 \alpha$ of presynch- 10 and on the day of the second GnRH of ovsynch may be due to this complex biological mechanism. We think that this situation may be the reason that a correlation could not be established between serum $I G F-1$ levels and endometrial IGF-1 expression levels.

In conclusion, in addition to this study, which examined the $I G F-1$ expression profile in conjunction with administration of the presynch-10+ ovsynch protocol for the purpose of treating SE, new studies that investigate all of the elements of the IGF system and not only endometrial expression levels but also expression in follicles, corpus luteum and liver tissue could help develop new approaches when it comes to solving the repeat breeder problem, which is important to livestock breeders.

\section{Acknowledgements}

This study was presented in the Turkish Veterinary Gynecology Association, VIII. National \& II. International Congress, 10-13 October 2019, Antalya.

\section{Financial Support}

This study was supported by the TUBITAK (Project No. 1130590).

\section{Conflict of Interest}

The authors declared that there is no conflict of interest.

\section{References}

1. Adnane M, Kaidi R, Hanzen C, et al (2017): Risk factors of clinical and subclinical endometritis in cattle: a review. Turk J Vet Anim Sci, 41, 1-11.

2. Agaoglu AR, Agaoglu OK, Aslan S, et al (2020): The effects of presynch-10 and ovsynch on some endometrial toll and nod-like receptor gene expressions in repeat breeder cows. Kafkas Univ Vet Fak Derg, 26, 111-120.

3. Albihn A, Gustafsson H, Hurst M, et al (1991): Embryonic ability to prolong the interestrous interval in virgin and repeat breading heifers. Anim Reprod Sci, 26, 193-210.

4. Albihn A, Gustafsson H, Rodriguez-Martines H, et al (1989): Development of day 7 bovine demi embryos transferred into virgin and repeat breeder heifers. Anim Reprod Sci, 21, 161-176.
5. Bitar MS (2000): Insulin and glucocorticoid-dependent suppression of the IGF-I system in diabetic wounds. Surgery, 127, 687-695.

6. Burns PD, Spitzer JC, Henricks DM (1997): Effect of dietary energy restriction on follicular development and luteal function in nonlactating beef cows. J Anim Sci, 75, 1078-1086.

7. Geisert RD, Lee CY, Simmen FA, et al (1991): Expression of messenger RNAs encoding insulin-like growth factor-I, II, and insulin-like growth factor binding protein-2 in bovine endometrium during the estrous cycle and early pregnancy. Biol Reprod, 45, 975-983.

8. Ghahary A, Chakrabarti S, Murphy LJ (1990): In situ localization of the sites of synthesis and action of insulinlike growth factor-1 in the rat uterus. Mol Endocrinol, 4, 191-195.

9. Giudice LA, Dsupin BA, Jin IH, et al (1993): Differential expression of messenger ribonucleic acids encoding insulin-like growth factors and their receptors in human uterine endometrium and decidua. J Clin Endocrinol Metab, 76, 1115-1122.

10. Grazul-Bilska AT, Johnson ML, Bilski JJ, et al (2003): Wound healing: the role of growth factors. Drugs Today, 39, 787-800.

11. Gustafsson Hi Larsson K, Kindahl H, et al (1986): Sequential endocrine changes and behaviour during estrus and metestrus in repeat breeder and virgin heifers. Anim Reprod Sci, 19, 261-273.

12. Janowski T, Barański W, Lukasik K, et al (2013): Prevalence of subclinical endometritis in repeat breeding cows and mRNA expression of tumor necrosis factor $\alpha$ and inducible nitric oxide synthase in the endometrium of repeat breeding cows with and without subclinical endometritis. Pol J Vet Sci, 16, 693-699.

13. Kasimanicam R, Kasimanicam V, Kastelic JP (2014): Mucin 1 and cytokines mRNA in endometrium of dairy cows with postpartum uterine disease or repeat breeding. Theriogenology, 81, 952-958.

14. Khair A, Asuduzzaman M, Sultana Z, et al (2018): Economic benefit in repeat breeder cows using intrauterine infusion of penicillin and estrus synchronization followed by timed artificial insemination. J Adv Vet Anim Res, 5, 454458.

15. LeBlanc SJ, Duffied TF, Leslie KE, et al (2002): Defining and diagnosing postpartum clinical endometritis and its impact on reproductive performance in dairy cows. J Dairy Sci, 85, 2223-2236.

16. Livak KJ, Schmittgen TD (2001): Analysis of relative gene expression data using real-time quantitative PCR and the $2-{ }^{\Delta \Delta T}$ method. Methods, 26, 402-408.

17. Llewellyn S, Fitzpatrick R, Kenny DA, et al (2008): Endometrial expression of the insulin-like growth factor system during uterine involution in the postpartum dairy cow. Dom Anim Endocrinol, 34, 391-402.

18. Lucy MC, Bilby CR, Kirby CJ, et al (1999): Role of growth hormone in development and maintenance of follicles and corpora lutea. J Reprod Fertil, 54, 49-59.

19. Mandefro M, Negash G (2014): Repeat breder syndrome in dairy cows: Influence of Breed and Age on Its Prevalence. World J of Agric Sci, 10, 200-203. 
20. Mann GE, Green MP, Sinclair KD, et al (2003): Effects of circulating progesterone and insulin on early embryo development in beef heifers. Anim Reprod Sci, 79, 71-9.

21. Mann GE, Lamming GE (2001): Relationship between maternal endocrine environment, early embryo development and inhibition of the luteolytic mechanism in cows. Reproduction, 121, 175-80.

22. Neuvians TP, Pfaffl MW, Berisha B, et al (2003): The mRNA express, one of the members of the IGF system in bovine corpus luteum during induced luteolysis. Dom Anim Endocrinol, 25, 359-372.

23. Parkinson TJ (2009): The repeat breeder syndrome. 463466. In: DE Noakes, TJ Parkinson, GCW England, (Eds), Veterinary reproduction and obstetrics. 9th ed., Saunders Elsevier, Edinburgh.

24. Pothmann H, Prunner I, Wagener K, et al (2015): The prevalence of subclinical endometritis and intrauterine infections in repeat breeder cows. Theriogenology, 83, 1249-1253.

25. Pursley JR, Mee MO, Wiltbank MC (1995): Synchronization of ovulation in dairy cows using $P G F 2 \alpha$ and GnRH. Theriogenology, 52, 1067-1078.

26. Radcliff RP, McCormack BL, Crooker BA, et al (2003): Plasma hormones and expression of growth hormone receptor and insulin-like growth factor-I $m R N A$ in hepatic tissue of periparturient dairy cows. J Dairy Sci, 86, 39203926.

27. Robinson RS, Mann GE, Gadd TS, et al (2000): The expression of the IGF system in the bovine uterus throughout the oestrous cycle and early pregnancy. J Endocrinol, 165, 231-243.

28. Salasel B, Mokhtari A, Taktaz T (2010): Prevalence, risk factors for and impact of subclinical endometritis in repeat breeder dairy cows. Theriogenology, 74, 1271-1278.

29. Simmen RCM, Simmen FA, Hofig A, et al (1990). Hormonal regulation of insulin like growth factor gene expression in pig uterus. Endocrinology, 127, 2166-2174.
30. Souza AH, Gümen A, Silva EPB, et al (2007) Supplementation with estradiol-17 $\beta$ before the last gonadotropin-releasing hormone injection of the ovsynch protocol in lactating cows. J Dairy Sci, 90, 4623-4634.

31. Spicer LJ, Echternkamp SE (1995): The ovarian insulin and insulin-like growth factor system with an emphasis on domestic animals. Dom Anim Endocrinol, 12, 223-245.

32. Stevenson KR, Gilmour RS, Wathes DC (1994): Localization of insulin-like growth factor-I (IGF-I) and -II messenger ribonucleic acid and type 1 IGF receptor in the ovine uterus during the oestrous cycle and early pregnancy. Endocrinology, 134, 1655-1664.

33. Totey SM, Pawshe CH, Rao KBC (1996): In vitro maturation of buffalo oocytes: Role of insulin and its interaction with gonadotrophins. J Reprod Fertil, 50, 113-119.

34. Valdmann M, Kurykin J, Kaart T, et al (2018): Relationships between plasma insulin like growth factor-1 and insülin concentrations in multiparous dairy cows with cytological endometritis. Vet Rec, 183, 1-7.

35. Wathes DC, Cheng Z, Fenwick MA, et al (2011): Influence of energy balance on the somatotrophic axis and matrix metalloproteinase expression in the endometrium of the postpartum dairy cow. Reproduction, 141, 269-281.

36. Wodaje HB, Mekuria TA (2016): Risk factors of repeat breeding in dairy cattle. Adv Biol Res, 10, 213-221.

37. YoshidaY, Miyamura M, Hamano S, et al (1998): Expression of growth factor ligand and their receptor mRNAs in bovine ova during in vitro maturation and after fertilization in vitro. J Vet Med Sci, 60, 549-554.

38. Yusuf M, Nakao T, Ranasinghe RB, et al (2010): Reproductive performance of repeat breeders in dairy herds. Theriogenology, 73, 1220-1229.

39. Zobel R, Tkaltcic S, Buic V, et al (2011): Repeat breeder syndrome in dairy cows: influence of breed and age on its prevalence and the success of a hormone therapy. Turk J Vet Anim Sci, 35, 405-411. 